\title{
The Role of Natural and Human-Mediated Pathways for Invasive Agricultural Pests: A Historical Analysis of Cases from Brazil
}

\author{
Marcelo Lopes-da-Silva', Marcio Martinello Sanches', Andréa Ramos Stancioli², \\ Giliardi Alves², Regina Sugayama² \\ ${ }^{1}$ Plant Quarantine Laboratory, Embrapa Genetic Resources and Biotechnology, Brazilian Agricultural Research \\ Corporation (Embrapa), Brasilia, Brazil \\ ${ }^{2}$ Agropec Pesquisa, Extensão e Consultoria, Belo Horizonte, Brazil \\ Email: marcelo.lopes.silva@embrapa.br, marcio.sanches@embrapa.br
}

Received 25 April 2014; revised 29 May 2014; accepted 18 June 2014

Copyright $@ 2014$ by authors and Scientific Research Publishing Inc.

This work is licensed under the Creative Commons Attribution International License (CC BY).

http://creativecommons.org/licenses/by/4.0/

(c) (†) Open Access

\section{Abstract}

Information about the geographic distribution of agricultural pests is the basis for all pest-related agricultural and environmental protection policies. However, often the pest's records are incomplete and uncertain. Even with limitations, the pest records are needed for any country to organize a system for agriculture protection and to mobilize surveillance efforts. The first point is to identify the imminence of biological invasions, which can be accomplished through the collection of data on pest distribution. The basic information to evaluate the predictability of an invasion is geographic distribution and the identification of pathway types associated with the potential invader. Thus, the level of the risk of introduction is assessed more objectively. In this article, cases of introduction of pests were analyzed from published reports in Brazil in terms of their geographic distribution at the time of their introduction. Taking into consideration the country's extensive terrestrial borders, this study attempts to elucidate the role played by different pathways in each bioinvasion. This analysis recognized the limitations of the historical method and underlying uncertainties of each invasion event. Human-mediated pathways were the main source of agricultural pest invasions in Brazil and the country was more a disperser than a receptor of exotic agricultural pests and diseases in South America. A new geographical hotspot (Northern South America and Caribbean Region) for possible invasions was identified.

\section{Keywords}

Bioinvasions, Biosecurity, Surveillance, Borders, Dispersion, Invasion Biology, Risk Analysis 


\section{Introduction}

If there is an event that would be considered a landmark in the world history of plant protection policies it is the introduction of Phylloxera in Europe [1]. In 1881, the Phylloxera Convention, in Berne, was the first international treaty that stood for an agreement about efforts of European countries to cooperate with general plant security policies in order to control an agricultural pest [2]. In 1951, under the auspices of the Food and Agriculture Organization (FAO), a more inclusive and representative Convention was created: The International Plant Protection Convention (IPPC) [2]. Another important international treaty regarding agriculture biosecurity is the SPS Agreement (Agreement on the Application of Sanitary and Phytosanitary Measures) of the WTO (World Trade Organization) that among other principles, establishes that phytosanitary measures should rely on technical basis and be justifiable. In the case of agricultural products commerce, trade obstacles are justifiable only if the importing country provides scientific evidence of the high risk of introduction of an agricultural pest. In this case, the risk must be managed to an acceptable level and preparedness is the most important basis of plant protection policy, because there is no zero risk level. Another important source of uncertainty for plant protection policies is the lack or insufficiency of official records. Precise information on the existence of pests occurring in the exporting country is the basis for pest risk analysis. However, national pest records are not standardized and there are unreliable records. This results in an uncertainty level for risk analysis that has to be managed carefully by the National Plant Protection Organization (NPPO) of each importing country.

Despite the fact that the risk of pest introduction from traded agricultural products is manageable, many biological invasions continue to occur worldwide [3]. Under this hypothesis, many pest invasions can be attributed to the failure of risk analysis and surveillance systems. However, according to the pest's characteristics, many invasions are unavoidable. A country could have an efficient system of risk management and prevention, but in some cases if a neighboring country has suffered a pest invasion, the best policy is to be prepared for the invasion. In this case, border monitoring for early detection and detailed mitigation planning must be implemented. Also, permanent prospection of data on pest occurrence in neighboring countries and international trade partners should be used to determine the need of reviewing established policies.

Brazil has a growing agricultural sector which plays a major role in the country economy. About 40\% of Brazil's GDP comes from agribusiness, which includes production systems in the field and industries linked to agricultural product processing. In the last decades of the $20^{\text {th }}$ century, new agricultural frontiers transformed Central Brazil into the largest tropical climate zone agricultural area in the world. This increase in agricultural areas had an important side-effect: secondary native pests became major pests in the new agricultural environment and this changing environment seems to be susceptible to invasive species from other tropical zones of the world. The most damaging pests for Brazilian agriculture in the early years of the $21^{\text {st }}$ century are some relatively new invaders: the boll weevil (Anthonomus grandis), the whitefly (Bemisia tabaci) biotype B, Asian Soybean Rust (Phakosphora pachyrhizi) and the Old World bollworm (Helicoverpa armigera).

Pests are becoming an important component of agricultural production costs. Some estimates say Brazil is the biggest market in the world for chemicals to combat pests and also, a promising market for biological control products. In 2011, the Brazilian market for pesticides was more than US\$ 8.5 billion [4]. In some crops, such as cotton, pest control costs are approximately $25 \%$ of total production costs [5]. The average number of pesticide spraying is two up to seven in soybean [6] and 12 - 14 in cotton [7]. Integrated pest management systems are developed for a fixed scenario of pests and the dynamics of invasions are forcing rapid changes in threshold levels for control. Therefore, if an agricultural pest invasion is strongly expected and unavoidable, many actions for preparedness compensate the cost of reactive actions.

The aim of this review is to elucidate whether there are some historical patterns in agricultural pest invasions using Brazil as a model country with extensive terrestrial borders and intensive offshore movement of agricultural goods.

\section{Limitations of Historical Analysis of Pest Invasions}

\subsection{Discontinuous and Continuous Pest Distribution: When the Map Is Not Filled}

The phrase "absence of evidence is not evidence of absence" fits perfectly the precautionary consideration of pest absence. It is not possible to consider pest absence as an absolute fact. Absence of records of pests of high mobility in countries or neighboring areas close to where they are present must be considered an uncertainty. 
Published surveys or check-lists of species are an excellent source of information, but they are getting rarer nowadays. Lists of species contained in museums are reliable information, but many times they can be outdated. The disparity of available information of a species' distribution is another factor that can be a source of uncertainty for any prediction of an invasive species' spread. It seems obvious that invasions would be more predictable if the pest databases about geographical distribution were comprehensive. In this analysis, some pest records of Brazil are exclusively available from national sources with limited access. Many reports were published in obscure and outdated publications. It is impossible to gather all information available and store it in large databases without any evaluation of whether the information is reliable. Quarantine pest occurrence, according to IPPC, should be confirmed by an official notification from the NPPO representative of the country.

Uncertainty related to the absence of records must be analyzed in the form of possibilities. Firstly, are the gaps, in fact, an indication of a real discontinuity of the pest's geographical distribution? Secondly, the gaps may be a result of absence of records, where absence is dubious. In order to illustrate these assumptions and to make an attempt at avoiding subjective judgments, there are some historical examples of pest invasions in Brazil that can be analyzed in order to shed light on this issue. The cotton boll weevil, Anthonomus grandis, one of the most serious pests of cotton, was found in Brazil in 1983 [8]. This insect is native to Mexico and in 1892; the boll weevil entered the United States, where it rapidly became the most damaging pest of cotton [9]. The presence of the boll weevil in Central America and in the Caribbean islands was recorded during the 1960s-1970s, but these records are not referred to as "first" records. It is very probable that the boll weevil was active in all Central America and in the Caribbean region before the 1950s [10]. This is supported by museum specimens collected in 1902, in the Cayman Islands and 1906 near Havana, Cuba and specimens found in cotton from Guatemala in 1906.The first reference to the presence of the boll weevil in South America was in 1949, in Venezuela [10] and boll weevil was first recorded in Colombia in 1950. Since then, it has dispersed throughout the Atlantic Coast; in 1980, it was found in the region of Puerto Boyaca [11]. If these two national records were available and published at that time and there was no information of the existence of museum specimens, prior to 1966, the scenario of the boll weevil distribution would be a gap between North America and Northern South America. After 1966, a continuous distribution and probably an expansion to the southern and southeastern USA and to the northern and central regions of South America easily could be presumed. In fact, the expansion to South America was predictable and the detection of A. grandis in Brazil was not surprising. In the same year of detection, the pest was found in the cotton fields of Northeastern Brazil and it could be interpreted as an expansion of boll weevils from southeast to northeast. However, a discontinuous hypothesis for boll weevil introduction was supported by experts [12] and they affirmed that the boll weevil was introduced to Brazil by air cargo [12]. The first detection in São Paulo was in February 1983 [12] and the first detection in Paraiba (NE Brazil) was in July 1983 [12]. This is a short time for an introduced population to spread vastly across the Brazilian territory. In terms of U.S. distances and considering that the first detection of the boll weevil was in Brownsville, Texas, 1892, it would be equivalent to finding $A$. grandis in North Dakota in the same year. Therefore, it is more probable that boll weevil introduction in Brazil fits the scenario of natural expansion without monitoring and it was found only when the population reached the theoretical "detection point”.

There are good examples of the gaps that can be considered "real gaps” with detection records depicting distribution maps that are discontinuous. A typical example is of pest records from Islands wherethe ocean works as a natural barrier for pest spreading. Although the pest can spread naturally (active dispersion or passive dispersion by the wind), a discontinuous distribution is expected as a result of human interference. The red palm mite (Raioella indica) is a typical species with geographically discontinuous records. This mite was first described as a species by Hirst in India [13]. The red palm mite was detected in Egypt [14], Sudan in 1938 [15], Mauritius [16] and Saudi Arabia [17]. Geographical distribution gaps are filled with records in Pakistan [18] and Iran [19]. Despite an absence of records in Afghanistan and Iraq, only the record in Mauritius could be considered likely to be human-mediated introduction. However, this pest was unexpectedly found on Martinique Island, in the Caribbean Sea [20]. This mite rapidly spread across the Caribbean, being detected in the United States in 2007, Venezuela in 2007 and Brazil in 2009 [21]. This case is particularly interesting because, before the introduction in Martinique, this invasion in Brazil could be classified as highly unlikely at least in the short term. The role played by abiotic agents was unknown until the Caribbean invasion. Wind must be a primary pathway, with handicraft and plant trade as the most probable pathway [22]. The red palm mite detection in Brazil in 2009 was a result of investigative observation, but it would be highly predictable following Venezuela's detection in 2007. 
One of the most unexpected cases of invasions in Brazil was Asian soybean rust (Phakosphora pachyrhizi) in 2002 and the agent of sugarcane orange rust (Puccinia kuehnii) in 2009. The detections of P. pachyrhizi in Brazil and Paraguay were almost simultaneous. These records seem to be the first detection of Asian soybean rust in the Americas. Soybean rust had spread across Africa during the 1990s. In 2001, it was found in South Africa and Zimbabwe. If a natural spreading hypothesis is postulated, a transoceanic movement of $P$. pachyrhizi spores must be considered. Long distance movement of pathogens seldom occurs, but there are some examples of possible transoceanic movement mediated by air masses [23]. The example of orange rust of sugarcane in the Americas, caused by $P$. kuehnii, is different and probably more complex than the $P$. pachyrhizi case. This disease was considered absent of Africa and the hypothesis of transoceanic movement would not be probable. $P$. kuehnii was not reported in the Americas until 2007, the year when this fungus was reported occurring on sugarcane in Florida [24]. Rapidly, several “first reports” appeared: Guatemala [25], Costa Rica and Nicaragua [26], El Salvador, Mexico and Panama [27], Colombia [28]. All of these sequential records can be attributed to monitoring for pest occurrence by plant pathologists. However, in 2011, P. kuehnii was found in Africa, in Cameroon. This fungus was first reported in Brazil in 2009. The rapid spreading across the world occurred after a severe epidemic in Australia in 2000. The hypothesis of natural dispersion reaching the Americas (consequently Brazil) is very weakly supported by an analysis of available reports. It seems possible that the movement of sugarcane internodes with leaves across the world was the start of the global spreading of $P$. kuehnii. This is supported by a few host plants species (almost all Saccharum sp.) and alternative hosts of the closely related genera Erianthus, Sclerostachya, and Narenga [29].

\subsection{Accessibility and Availability of Agricultural Pest Information}

Information about pest occurrence is pivotal for any pest surveillance service. Nowadays there are excellent international sources available on the internet. The CABI Compendium (www.cabi.org/cpc) is a result of an international effort and it is an initiative of over 40 partners. This online compendium is the primary source of pest information. Another excellent sources are PQR (Plant Quarantine data Retrieval), the database about quarantine pests developed by EPPO (European Plant Protection Organization) and available on www.eppo.int and the Global Biodiversity Information Facility (GBIF) (http://www.gbif.org/) that relies on data provided by 605 contributors worldwide.

However, information about pests, especially invasive pests that are recognized as being of little importance, is difficult to be found. From the cases of invasive pests in Brazil with published records, there is no substantial information about 14, even today. Many times, the species is not recognized as a pest in its original region. The typical example is the Australian bronze bug, Thaumastocorius peregrinus, which was a relatively unknown species until 2002, when an outbreak occurred in Sydney, Australia, on Eucalyptus. This species invaded South Africa in 2003 and was found in Argentina in 2005, Uruguay in 2008 and eventually in Brazil in 2009 [30]. In Africa, T. peregrinus was recorded in Zimbabwe (2007) Malawi (2008) and Kenya (2009) [31]. In 2011, T. peregrinus was found in Italy and in 2012 in Portugal [31]. The bronze bug is a typical recent global invader, rapidly spread across the world and its probable pathway is transportation on Eucalyptus for planting, cut branches and as a hitchhiker on wood [32]. In all these cases, all the information that has been generated about the bronze bug comes from invaded areas. This pest was not recognized as a quarantine pest for Brazil before the invasion and due to its characteristics of rapid spreading, it is not possible that $T$. peregrinus be regulated as a quarantine pest. In 2012, EPPO put T. peregrinus on the alert list. Another invasion with similarities to the T. peregrinus case was that of the African fig fly Zaprionus indianus. This invasion occurred without any previous signs. In fact, there was not any substantial information about this drosophilid, whose origin is admitted to be Africa, but its first description is from specimens from India [33]. This species spread all throughout the Americas and reached Canada [34]. One of the most obscure invasive pests in Brazil is the citrus hindu mite Schizotetranychus hindustanicus. This mite was originally described on citrus from Coimbatore, southern India and after almost 80 years of its description, Quirós \& Geraud-Pouey [unpublished] reported it in Zulia, northwestern Venezuela [35]. There were no records of this mite species until 2010, when it was found in Iran [36]. Citrus is an important commodity for Brazil and despite lack of essential information about biology, ecology and damage, S. hindustanicus is subject to phytosanitary regulation in Brazil in order to restrict it to Roraima state, Northern Region. Studies performed by Fantine et al. (in press) suggest that it may have been introduced in Brazil through the illegal trade of plant propagation material from Venezuela. 


\subsection{Misidentification and Lack of Scientific Research}

Inaccurate records of exotic pests in Brazil also occurred. The best known case is that of the chinch bug Blissusleucopterus. This pest of grasses was first found in Minas Gerais in 1975 and later it was found in Rio de Janeiro in 1980 and Mato Grosso do Sul [37]. However, these records are considered as a misidentification because the putative B. leucopterus was restricted to Tanner grass and in the USA it is an important pest for cereals like sorghum and several grasses. B. leucopterus, in fact, is B. antillus after a careful taxonomic examination [37]. This misidentification came from the information that B. leucopterus was present in South America on a taxonomic list [38].

Another source of high uncertainty is the lack of scientific research about pests in developing countries. Commercial embargoes against agricultural products are more likely to be imposed by countries with more advanced research about pests than by countries that do not have extensive pests records [39]. This matter has been the subject of accordance in the SPS agreement, which contains rules that enforce transparency and collaboration between countries in order to export and import agricultural products with an acceptable level of risk.

\section{Natural $x$ Human-Mediated Pathways}

\subsection{Classifying Pathways}

Pest pathways are so diverse that is unlikely to identify all possibilities. However, within the scenario of a pest surrounding an area considered under threat, it would be simple to consider the introduction event highly predictable. Generic pathways based on the ability of the pest to spread could be categorized. Proposed here are six major types of pathways classified in two groups, shown in Table 1.

Pest introduction by pathway 1 occurs when the pest can move by itself (flying or walking). Pathway 2 occurs when the pest can be transported by an active vector, like a plant virus carried by a vector insect or a seed adhered to livestock skin. Pathway 3 is when rainfall and winds are responsible for spreading noxious organisms. On the other hand, human-mediated pathways involve the transportation of pest together with a plant or plant part or agricultural product (Pathway 4). Pathway 4 is the only one that has been regulated in order to manage the risk of pest introduction around the world. Pathway 5 rarely happens and characterizes situations where the pest is a hitchhiker and is found, for example, on the human body, clothes or shoes and Pathway 6 include the intentional introduction of an organism of potential economic importance than may become a pest as well as bioterrorism.

If a given pest is present in a neighboring country, pathways 1, 2 and 3 have unmanageable risk, regardless of the effort applied by the country under risk. Every pest has a natural pathway, sometimes more than one, but one of the natural or human-mediated pathways is more common and it is called here the primary pathway. It is important to define the difference between the primary pathway and the probable pathway of introduction. Sometimes they are the same, sometimes not. As an example, if a quarantine pest is on the other side of a political border and it is an efficient flying organism (an insect like a moth), its introduction will be just a matter of time. This is a highly probable event. However, there is another way for this insect to cross the border. It can be introduced by transport of immature non-flying forms living on parts of plants. This is a secondary or even, a tertiary pathway and its risk can be managed by use of regulations to restrict infested plants; however, it is impossible to avoid this introduction because the primary pathway is active dispersion by flying. Therefore, active dispersion (primary) is the highly probable route of introduction.

Another example is when an efficient flying insect occurs far from the endangered area, for example, on the other side of the ocean, in other continent. In this case, if the pest is found thousands of miles away, across the ocean, the natural or primary pathway is not the most probable pathway of introduction. An example of this in

Table 1. Classifications of pathways for agricultural pests.

\begin{tabular}{ll}
\hline \multicolumn{1}{c}{ Natural } & \multicolumn{1}{c}{ Pathways } \\
\hline 1. Active dispersion & \multicolumn{1}{c}{ Human-mediated } \\
2. Passive transport by biotic agent & $\begin{array}{l}\text { 4. Passive transport with plant or other material } \\
\text { 5. Accidental transport }\end{array}$ \\
3. Passive transport by abiotic agent & 6. Intentional introduction \\
\hline
\end{tabular}


Brazil historical records is of the pest invasion by the medfly (Ceratitis capitata). Probably, Brazil was the first country in the Americas infested by the medfly and its origin was West Africa according to the mtDNA similarity [40]. Medfly was able to spread flying across the African continent, but was unable to cross the ocean, and probably it was introduced to Brazil inside of infested fruits brought by early colonizers of the country.

\subsection{Studies Cases}

In this analysis, 65 cases of pest introduction with consistent reports were examined (Table 2). The reports were placed as bars on a time-line in order to verify the distribution of the records on the scale of time from 1901-2013 (Figure 1). The geographical distribution of each pest before the first detection in Brazil was obtained using extensive searching of databases. For each pest one up to three primary pathways and the probable pathway of introduction were attributed. From the cases analyzed, 24 cases of pest introduction were first recorded in Brazil. In some of those cases, the pest remains confined inside the Brazilian territory. An example is Singhiella simplex, a whitefly that is a pest of trees in urban areas, especially Ficus benjamina. This pest was reported in the Cayman Islands, Puerto Rico and in Florida, in the continental United States, in 2007. In 2009, S. simplex was found damaging Ficus in the city of Rio de Janeiro and in 2013, a massive attack occurred in Belo Horizonte, Minas Gerais [41].

The most emblematic case is the Helicoverpa armigera introduction. This pest was first reported in Brazil in 2013 [42] and since its detection in Bahia, several states confirmed pest presence. H. armigera had an enormous negative impact on cotton, soybean, bean, tomatoes and corn production with estimated damages of over US\$ 2 billion since 2012, the year of presumed first outbreak. There is no clue about the probable pathway of introduction. Importation of cut flowers, ornamentals and fruits is a pathway with low risk of introduction of $H$. armige$r a$ [43]. Natural dispersal is considered the most probable pathway of $H$. armigera introduction and spread in Europe from its native range. Nevertheless it is unreasonable to suppose that it reached Brazil by active means as countries where it occurs are more than an ocean away. Monitoring the H. armigera's spread across the countries of Americas will be mandatory since this species is very similar to the New World's Helicoverpa zea species and its control has been a challenge.

Considering the importance of transboundary movements of pests and their direct relationship with invasions of plant pests in Brazil, two major entry points are easily recognized. The first is the southern border: Argentina and Uruguay. At least ten exotic forest and fruit pests of subtropical climate were recorded before in the countries of the Southern Cone: Uruguay, Argentina and Chile. The second important entry point for pests in Brazil is the northern borders: Colombia, Venezuela, Guyanas Suriname and, with the exception of the controversial A. grandis case, at least nine cases have evidence of active or passive pest movement towards Brazil. The majority of these pests were from the Caribbean region, which could be considered a hotspot of invasive pests for both North and South America.

Overall, the majority of the cases (at least 38) are pests that are able to spread actively, but from these cases, 12 could be related to transboundary movement. It means that in one in four cases, it highly probable that the pest moved by itself, actively searching for a host plant across the neighboring country and Brazilian borders. These events are excellent cases studies for preparedness of quarantine actions.

Considering that these invasion events were unavoidable, the time lag from pest detection in the neighboring country to the record in Brazil must be enough to launch protective actions. This time for invasiveness was very variable in the case of active-dispersed pests. For example, the time was long for Anthonomus grandis (34 years, if we consider the natural dispersion hypothesis for boll weevil invasion in Brazil). Another curculionidae beetle, Gonipterus scutellatus, an excellent flying insect, was recorded in Argentina in 1925 [44] and in Brazil, in 1955 [45]. Considering that the last South American record of the Citrus black fly (Aleurocanthus woglumi) before the Brazilian record was in Colombia, in 1975, there was a time interval of 26 years. The carambola fruit fly (B. carambolae) was detected in Suriname in 1975 and the first record in Brazil was in 1996 (21 years later) [32]. Another pest with a relatively long time between the Brazilian record and another South American record is the whitefly Parabemisia mirycae. This whitefly was recorded in Venezuela 16 years before Brazil.

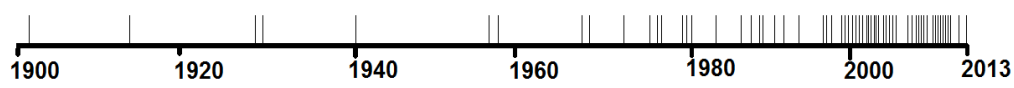

Figure 1. Timeline (1901-2013) of published invasive agricultural pest records in Brazil. Each vertical trace indicates the reported year of pest detection. 
Table 2. Reports of first detection of agricultural pests in Brazil from 1901-2013.

\begin{tabular}{|c|c|c|c|}
\hline \multirow[b]{2}{*}{ Pest } & \multicolumn{3}{|c|}{ Pathways ${ }^{*}$} \\
\hline & $\begin{array}{l}\text { South American country } \\
\text { of first record }\end{array}$ & $\begin{array}{l}\text { Primary } \\
\text { pathways }\end{array}$ & $\begin{array}{c}\text { Probable } \\
\text { pathways of introduction }\end{array}$ \\
\hline Ceratitis capitata & Brazil & 1,4 & 4 \\
\hline Hypothenemus hampei & Brazil & 1,4 & 4 \\
\hline Grapholita molesta & $?$ & 1 & $?$ \\
\hline Diaphorina citri & Brazil & 1 & 4 \\
\hline Xanthomonas axonopodis & Argentina & 3,4 & 4 \\
\hline Gonipterus scutelattus & Argentina & 1 & 1 \\
\hline Phoracantha semipunctata & $?$ & 1,4 & 4 \\
\hline Stenodiplosis sorghicola & $?$ & 1 & $?$ \\
\hline Erosomyia mangiferae & Brazil & 1,4 & 4 \\
\hline Clavibacter michiganensis & $?$ & 4 & 4 \\
\hline Opogona sacchari & Brazil & 1 & 4 \\
\hline Ralstonia solanacearum race 2 & Venezuela & 4 & 4 \\
\hline Panonychus ulmi & $?$ & 3,4 & 4 \\
\hline Gonipterus scutellatus & Brazil & 1 & 4 \\
\hline Tuta absoluta & Argentina & 1 & 1 \\
\hline Guignardia citricarpa & Brazil & 4 & 4 \\
\hline Anthonomus grandis & Venezuela & 1 & 1 or 4 \\
\hline Conotrachelus denieri & Argentina or Paraguay & 1 & 1 \\
\hline Xylella fastidiosa & Argentina & 2,4 & 4 \\
\hline Sirex noctilio & Uruguay & 1,4 & 4 \\
\hline Bemisia tabaci B biotype & Brazil & 1 & 1 or 4 \\
\hline Cydia pomonella & Chile & 1,4 & 4 \\
\hline Thrips palmi & Venezuela & 1 & 1 \\
\hline Bactrocera carambolae & Suriname & 1 & 1 \\
\hline Dactylopius opuntiae & Brazil & 1,4 & 6 \\
\hline Phyllocnistis citrella & Brazil & 1 & 1 \\
\hline Cinara pinivora & ? & 1,4 & 1 \\
\hline Cinara atlantica & ? & 1,4 & 1 \\
\hline Mycosphaerella fijiensis & Equador & 3,4 & 4 \\
\hline Xanthomonas campestris pv. Vitícola & $?$ & 4 & 4 \\
\hline Zaprionus indianus & Brazil & 1 & 4 \\
\hline Hyblaea puera & ? & 1 & 1 \\
\hline Pineus boeneri & Argentina & 1 & 1 \\
\hline Pissodes castaneum & Chile & 1 & 1 \\
\hline
\end{tabular}




\section{Continued}

\begin{tabular}{|c|c|c|c|}
\hline Aleurocanthus woglumi & Equador & 1 & 1 \\
\hline Phakosphora pachyrhizi & Brazil & 3,4 & 3 \\
\hline Sinoxylon conigerum & Venezuela & 4 & 4 \\
\hline Neonectria ditissima & Argentina, Chile, Uruguay & 3,4 & 4 \\
\hline Spodoptera albula & Colombia & 1 & 1 \\
\hline Epichrysocharis burwelli & $?$ & $?$ & $?$ \\
\hline Glicaspsis brimblecombei & Chile & 1 & 1 \\
\hline Greenidea ficicola & Brazil & 4 & 4 \\
\hline Candidatus liberibacter & Brazil & 2 & 4 \\
\hline Greenidea psidii & $?$ & 4 & 4 \\
\hline Plasmospora halstedi & Argentina, Chile, Uruguay & 3 & 3 \\
\hline Parabemisia myricae & Venezuela & 1 & $?$ \\
\hline Охусепиs maxwelli & $?$ & $?$ & $?$ \\
\hline Leptocybe invasa & Brazil & 1 & 1 or 4 \\
\hline Thaumastocoris peregrinus & Argentina & 1 & 1 \\
\hline Singhiella simplex & Brazil & 1 & 4 \\
\hline Raoiella indica & Venezuela & 1,3 & 4 \\
\hline Aceria tosichella & Argentina & $1,3,4$ & 4 \\
\hline Puccinia kuehnii & Brazil & 3,4 & 4 \\
\hline Schizotetranychus hindustanicus & Venezuela & 4 & 4 \\
\hline Elixothrips brevisetis & ? & 1 & 1 \\
\hline Aceria litchi & Brazil & 4 & 4 \\
\hline Duponchelia fovealis & Brazil & 1 & 1 \\
\hline Maconelicoccus hirsutus & Suriname, Venezuela and Guyana & 4 & 4 \\
\hline Helicoverpa armigera & Brazil & 1 & ? \\
\hline Lily mottle virus & Brazil & 2,4 & 4 \\
\hline Lily symptomless virus & Brazil & 2,4 & 4 \\
\hline Wheat streak mosaic virus & Argentina & 2,4 & 2 or 4 \\
\hline Tomato chlorosis virus & Brazil & 2 & 2 or 4 \\
\hline $\begin{array}{l}\text { Lettuce big-vein associated virus and } \\
\text { Mirafiori lettuce big-vein virus }\end{array}$ & Colombia & 2 & 5 \\
\hline Rice stripe necrosis virus & Colombia & 2 & 5 \\
\hline Shallot latent virus & Brazil & 2,4 & 4 \\
\hline
\end{tabular}

*Pathways: 1. Active dispersion, 2. Passive transport by biotic agent, 3. Passive transport by abiotic agent, 4. Passive transport with plant or other material, 5. Accidental transport, 6. Intentional introduction.

In other cases, the time interval is very short. The wood wasp, Sirex noctilio was found in 1985 in Argentina and in 1988 in Brazil, in the state of Rio Grande do Sul [46]. The bronze bug T. peregrinus was recorded in Argentina in 2005 and in Brazil in 2008 [30]. The bronze bug has spread to around 10 states of Brazil. The citrus 
hindu mite (S. hindustanicus) was another case with detection in Brazil only one year after detection in Venezuela. This shift from long time lag for pests first detected in South America from 1925 to 1975 (>15 years) and the short lag for pests detected in South America from 1985 to 2008 ( $<3$ years) may be attributed to the increase in trade as well as in international trips (and illegal entrance of agricultural items in the country). Thus, it is highly recommended that organisms engaged in plant protection should observe which pests are being reported in neighboring countries so as to anticipate biological invasion events, review policies and adjust emergency plans.

In this historical analysis, it was not possible to compare the interval time of records between the South American countries pest records and Brazilian records of pests with primary pathways 1 and 4 . There are few examples of pests with probable transportation in infested and infected plants or parts of plants from other Southern American Countries to Brazil. The detection of the causal agent of Citrus canker, the bacteria Xanthomonas axonopodis, occurred 24 years after its first record in Argentina [30]. However, two pests were rapidly detected in Brazil: Mycosphaerella fijiensis (2 years after being recorded in Peru and Bolivia) and Ralstonia solanacearum race 2, detected in Amapá, Brazil, only one year after the Venezuelan record. Coincidently, both of these pests have banana as the main host [30]. The fungus Plasmospora halstedii, whose major host is the sunflower (Helianthus annus), has records almost simultaneous in Chile, Argentina, Uruguay and Brazil and it is impossible to know where this pathogen was first appeared in South America.

The case of pests with primary pathways 2 and 4 comprises virus species. The plant viruses are transmitted mainly by vectors. From the eight viruses species introduced in Brazil, three are transmitted by aphids, one by whiteflies, one by mites and three by soil-borne vectors (one fungus and one protozoan). However, four listed species can also be naturally transmitted from plant parts: bulbs for Lily mottle virus (LMoV), Lily symptomless virus (LSV) and Shallot latent virus (SLV) and seeds for Wheat streak mosaic virus (WSMV). The manner that this last species was introduced in Brazil is unclear. The virus was reported in Argentina in 2002 [47], two years before the first report of its vector Aceria tosichella [48]. The introduction of contaminated wheat seed is the main hypothesis for the WSMV introduction in Argentina [49]. However, in Brazil A. tosichella was detected in 2006 [50] and the virus only in 2010 [51]. Due to the geographical proximity between countries, the introduction of the viruliferous mite from Argentina must be considered. The other case of introduction hypothesized by vector is Tomato chlorosis virus (ToCV) transmitted by Bemisia tabaci. The virus was detected in São Paulo State in 2006 [52] and until now, in South America, there are only reports in Brazil. Tomato is propagated mainly by seeds and this virus is not seed-transmitted. The molecular characterization of a Brazilian isolate suggests the introduction through plant exchange or by viruliferous vectors from Europe [53]. Both WSMV and ToCV are transmitted by vectors in a circulative manner, which is characterized by a long period of retention inside the vector. On the other hand, the cases where vectors are aphids: LMoV, LSV and SLV are transmitted in a non-circulative manner, characterized by the short-period in which the viruliferous vector is able to transmit the virus. The main hypothesis for the introduction of these viruses in Brazil is through contamined bulbs [54]-[56], because lily and garlic are propagated mainly from these parts of the plant. Accidental transport is the strongest hypothesis for the introduction of three viruses transmitted by soil-borne vectors. Big-vein disease of lettuce was detected in São Paulo State in 1998 [57] and it is a complex of two viruses transmitted by the fungus Olpidium brassicae. Although the fungus had been reported in the central part of Brazil before [58], the importation of contaminated peat is considered the pathway of introduction of the viruliferous fungus, as well as for the fungus Thielaviopsis basicola, the causal agent of black root rot of lettuce, introduced in the same period in São Paulo State [59]. An active dispersion of the soil-borne vector seems difficult to have occurred in the case of the introduction of Rice stripe necrosis virus (RSNV) in Brazil too. RSNV was first reported in Colombia in 1991 [60] and the second report in South America was in Rio Grande do Sul State in 2001 [61]. Despite the long interval, no more occurrences of RNSV between these two distant points were reported. Moreover, the main factor responsible for the rapid spread of the disease in Colombia seems to be the use of contaminated agricultural machinery shared by different rice growers.

At the end of the $20^{\text {th }}$ century, the Brazilian plant protection authority established that the importation of plants and plant material should be authorized only after a pest risk analysis. Before the SPS agreement, quarantine protection in Brazil was based on inspection and warranties of phytosanitary certificates. This is a paradox because cases of detection of agricultural pests increased in the last two decades despite improvements in the surveillance system. The transportation of plants across borders is the most important pathway for these invasive 
pests. There is a trend that the Amazon region is becoming a hotspot for new emerging exotic pests because at least six pests crossed the northern Brazilian borders since 1996 and they are spreading across the country. Detections of new invasive pests in northern Brazil are comprehensively difficult. The area is larger than all of Europe or Central America. Agricultural land area is increasing but is still very sparse, which is positive in quarantine terms because it is an obstacle to the natural spreading of pests. However, new roads, bridges, airports and other new infrastructure associated with Brazilian government policy to develop the Northern region can increase the risk of new pest entry mediated by human movement in Brazil.

In this analysis, in the last three decades, some invasions of agricultural pests were very predictable. Between 1980-1990, of six invasions, two were of pests from outside South America according to records and four were from South America. In the period 1990-2000, of 15 cases, seven were recorded previously in South America. Between 2000-2013, of 33 cases, 13 were present in a neighboring country before being recorded in Brazil. Considering that the time intervals were randomly chosen and even arranging these cases in other time intervals, there is not any tendency for invasions to come more from neighboring countries. The number of reported cases is not still sufficient for analysis, but in general terms, the majority of the cases of pests entering Brazil are associated with manageable pathways risks (imported plant or products, regulated or illegal).

Mankind depends on less than a dozen of the approximately 300,000 species of flowering plants for $80 \%$ of its caloric intake. This is not enough to support our food system in the future. Food availability must double in the next 25 years to keep pace with population and income growth around the world [62]. Therefore, agriculture tends to advance to new areas and to use different plant species. Countries tend to increase the exchange of plant materials. This scenario favors the emergence of new pests. The examples from Brazil might be applied worldwide to avoid the invasion of pests. Border surveillance has to be done together with implementation of government policies on trade of plant materials, as well as an integrated regional policy for plant protection between neighboring countries. In Africa, where many countries share similar characteristics with South American countries, and agriculture has been improving in the last decades, government efforts of countries to protect agriculture from pests must increase during the 21st century.

\section{Concluding Remarks}

Plant protection policies are limited by available information. This remark could be generalized to any country in the world. Some pests introduced in Brazil were practically unknown by the scientific community and sometimes of doubtful taxonomic status. An international effort is required to populate pest databases but it depends on government and private effort to implement driven monitoring systems for quarantine pests. In order to prevent and to manage invasions adequately, the Brazilian Ministry of Agriculture has elaborated some contingency plans, for example, a plan to avoid the entry and spread of Moniliophtora roreri, a pest of cacao and another contingency plan for Lethal Yellow Coconut, a pest of coconut. These are examples of actions taken based on recent information from reports indicating expansion of both pests. From all cases analyzed here, the number of pests whose probable pathway of introduction was human-mediated surpasses the cases of natural dispersion. Even in the cases of apparent transboundary movement, it was more probable that the pathway was an infected or infested plant transported to Brazil, the most common pathway for plant viruses. Active movement of invasive pests across borders was rare, but it was more probable in the case of some forests pests of Eucalyptus. Other natural pathways (wind and rainfall) were less probable. However, the pest of greatest economic impact to Brazilian agriculture, P. pachyrhizi (Asian Soybean Rust), seems to have arrived and spread in Brazil by air mass movement.

The time interval between the record of an invasive pest in a neighboring country and Brazil varied from one to 34 years. This timeframe allows elaboration of quarantine actions, but according to the Sugayama et al. (unpublished) there are at least 150 quarantine pests regulated by Brazil in South American countries. The prioritization of efforts of quarantine policies in order to define pests as targets of special regulations is important. Certainly, many of these policies could be based on the particularities of historical cases of agricultural pest invasion in Brazil.

\section{Acknowledgements}

We would like to thank Denise Návia (Embrapa) for providing us with interesting details about the introduction of mites and Mark Horn and Rick Harder for the revision of the manuscript. 


\section{References}

[1] Badia-Miró, M., Tello, E., Valls, F. and Garrabou, W.F. (2010) The Great Phylloxera Plague as a Natural Experiment: the Upkeep of Vineyards in Catalonia Spain (1858). Australian Economic History Review, 50, 39-61.

http://dx.doi.org/10.1111/j.1467-8446.2009.00271.x

[2] IPPC (2014) The International Plant Protection Convention. Historical Backgrounds. https://www.ippc.int/sites/default/files/documents/1161704216254_Handout00_IPPC_History_Member_-164617479.p df

[3] EEA (2012) The Impacts of Invasive Species in Europe. EEA Technical Report 16.

[4] Rojas, L. (2012) International Pesticide Market and Regulatory Profile. http://wcropchemicals.com/pesticide_regulatory_profile/

[5] Miranda, J.E. (2013) Perdas por pragas e impacto sobre o custo de produção do algodão brasileiro nas safras 2011/12 e 2012/13. IX Congresso Brasileiro de Algodão, Brasília.

[6] Quintela, E.D., Teixeira, S.M., Ferreira, S.B., Guimarães, W.W.F, Oliveira, L.F.C. and Czapak, C. (2007) Desafios para o Manejo Integrado de Pragas no Brasil Central. Comunicado Técnico 149. http://www.infoteca.cnptia.embrapa.br/bitstream/doc/213592/1/comt149.pdf

[7] Torres, J.B.(2007) Controle de Pragas do Algodoeiro. Ciência Agrícola, 8, 37-49.

[8] Habib, M.E.M. and Fernandez, W.D. (1983) Anthonomus grandis Boheman (Curculionidae) já está na lavoura algodoeira do Brasil. Revista de Agricultura, 58, 74.

[9] Lange, F., Olmestead, A.L. and Rhode, P.W. (2009) The Impact of Boll Weevil 1892-1932. Journal of Economic History, 69, 685-718. http://dx.doi.org/10.1017/S0022050709001090

[10] Warner, R.E. (1966) Taxonomy of the Subspecies of Anthonomus grandis (Coleoptera: Curculionidae). Annals of the Entomological Society of America, 59, 1073-1088.

[11] Lobaton, G.V. and Garcia, C.I. (1981) Some Aspects of the Biology of the Cotton Weevil Anthonomus grandis Boheman. Seminar Proceedings, Sociedad Colombiana de Entomologia, Bogota, 1-9.

[12] Barbosa, S., Braga S.R., Lukefahr, M.J. and Bengola, O.G. (1983) Relatório sobre ocorrência do bicudo do algodoeiro, Anthonomus grandis Boheman, "Boll Weevil” no Brasil e recomendações para sua erradicação. Campina Grande: EMBRAPA-CNPA, 12 p.

[13] Hirst, S. (1924) On some New Species of Bed Spider. Annals and Magazine of Natural History, 14, 522-527. http://dx.doi.org/10.1080/00222932408633151

[14] Taher, S.M. (1942) Contribution to the Knowledge of the Acarina of Egypt: I. The Genus Raoiella Hirst (Pseudotetranyehinae-Tetranyehidae). Bulletin de la Sociéte Fouad ler d'Entomologie, 26, 81-84.

[15] Pritchard, A.E. and Baker, E.W. (1958) The False Spider Mites (Acarina: Tenuipalpidae). University of California Publications in Entomology, 14, 175-274.

[16] Moutia, L.A. (1958) Contribution to the Study of Some Phytophagous Acarina and Their Predators in Mauritius. Bulletin of Entomological Research, 49, 59-75. http://dx.doi.org/10.1017/S0007485300053438

[17] Soliman, Z.R. and Al-Yousif, M.S. (1979) Prostigmatid Mites of Saudi Arabia (Acari, Acariformes: Prostigmata). Zoological Society of Egypt Bulletin, 29, 82-86.

[18] Mansoor-ul-Hassan, S.A. (2000) Genus Raoiella (Tenuipalpidae) from Date-Palm in Punjab-Pakistan. Pakistan Entomologist, 22, 11-13.

[19] Arbabi, M., Golmohammadzadeh Khiaban, N. and Askari, M. (2002) Plant Mite Fauna of Sistan-Baluchestan and Hormozgan Provinces. Journal of Entomological Society of Iran, 22, 1-17.

[20] Flechtmann, C.H.W. and Étienne, J. (2004) The Red Palm Mite, Raoiella indica Hirst, a Threat to Palms in the Americas (Acari: Prostigmata: Tenuipalpidae). Systematic and Applied Acarology, 9, 109-110.

[21] Navia, D., Marsaro, A.L., Silva, F.R., Gondim, M.G.C. and Moraes, G.J. (2011) First Report of the Red Palm Mite, Raoiella indica Hirst (Acari: Tenuipalpidae), in Brazil. Neotropical Entomology, 40, 409-411. http://www.scielo.br/ne http://dx.doi.org/10.1590/S1519-566X2011000300018

[22] Welbourn, C. (2006) Red Palm Mite, Raoiella indica Hirst (Acari: Tenuipalpidae). [Pest alert.] http://www.doacs.state.fl.us/pi/enpp/ento/r.indica.htm

[23] Nagarajan, S. and Singh, D.V. (1990) Long-Distance Dispersion of Rust Pathogens. Annual Review of Phytopathology, 28, 39-53. http://dx.doi.org/10.1146/annurev.py.28.090190.001035

[24] Comstock, J.C., Sood, S.G., Glynn, N.C., Shine, J.M., McKemy, J.M. and Castlebury, L.A. (2008) First Report of Puccinia kuehnii, Causal Agent of Orange Rust of Sugarcane, in the United States and Western Hemisphere. Plant 
Disease, 92, 175. http://www.apsnet.org

[25] Ovalle, W., Orozco, H., Quermé, J., Melgar, M. and García, S. (2009) Orange Rust in Guatemala and Management Strategies. Sugar Journal, 72, 18-25. http://www.sugarjournal.com

[26] Chavarría, E., Subirós, F., Vega, J., Ralda, G., Glynn, N.C., Comstock, J.C. and Castlebury, L.A. (2009) First Report of Orange Rust of Sugarcane Caused by Puccinia kuehnii in Costa Rica and Nicaragua. Plant Disease, 93, 425.

http://apsjournals.apsnet.org/loi/pdis http://dx.doi.org/10.1094/PDIS-93-4-0425C

[27] Flores, R.C., Loyo, J.R., Ojeda, R.A., Rangel, O.C.A., Cerón, F.A., Márquez, W., Guerra-Moreno, A.S, HernandezIbarra, H.M., González, R.E., Castlebury, L.A., Dixon, L.J., Glynn, N.C., Comstock, J.C., Flynn, J. and Amador, J. (2009) First Report of Orange Rust of Sugarcane Caused by Puccinia kuehnii in Mexico, El Salvador, and Panama. Plant Disease, 93, 1347. http://apsjournals.apsnet.org/loi/pdis http://dx.doi.org/10.1094/PDIS-93-12-1347B

[28] Cadavid, M., Ângel, J.C. and Victoria, J.I. (2012) First Report of Orange Rust of Sugarcane Caused by Puccinia kuehnii in Colombia. Plant Disease, 96, 143. http://apsjournals.apsnet.org/loi/pdis http://dx.doi.org/10.1094/PDIS-05-11-0406

[29] Ricaud, C., Egan, B.T., Gillaspie, A.G. and Hughes, C.G. (1989) Diseases of Sugarcane. Elsevier, Amsterdam, 189210.

[30] Wilcken, C.F., Soliman, E.P., Sá, L.A.N., Barbosa, L.R., Dias, T.K.R., Ferreira Filho, P.J. and Oliveira, R.J.R. (2010) Bronze Bug Thaumastocoris peregrines Carpintero and Dellapé (Hemiptera: Thaumastocoridae) on Eucalyptus in Brazil and Its Distribution. Journal of Plant Protection Research, 50, 201-205. http://www.plantprotection.pl http://dx.doi.org/10.2478/v10045-010-0034-0

[31] FAO (2012) Thaumastocoris peregrinus: Emerging Pest of Eucalipts in Native and Non-Native Regions of the Southern Hemisphere. http://www.fao.org/forestry/37416-068554951d2006931794ba801340d0ea2.pdf

[32] CABI (2014) CABI Compendium. http://www.cabi.org/cpc/

[33] Gupta, J.P. (1970) Description of a New Species of Phorticella and Zaprionus (Drosophilidae) from India. Proceeding Indian National Science, 36, 62-70.

[34] Renkema, J.M., Miller, M., Fraser, H., Légaré, J.P. and Hallett, R.H. (2013) First Records of Zaprionus indianus Gupta (Diptera: Drosophilidae) from Commercial Fruit Fields in Ontario and Quebec, Canada. Journal of the Entomological Society of Ontario, 144, 125-130. http://www.entsocont.com/pub.htm

[35] Navia, D. and Marsaro, A.L. (2010) First Report of the Citrus Hindu Mite, Schizotetranychus hindustanicus (Hirst) (Prostigmata: Tetranychidae), in Brazil. Neotropical Entomology, 39, 140-143. http://dx.doi.org/10.1590/S1519-566X2010000100021

[36] Sheikholeslamzadeh, S. and Sadeghi, H. (2010) First Records of Four Mite Species (Acari: Tetranychidae) in Iran. Applied Entomology and Phytopathology, 78, 121-125.

[37] Valerio, J.R., Vieira, J.M. and Valle, L.C.S. (1999) Ocorrência de Blissus antillus Leonard (Hemiptera: Lygaeidae: Blissinae) em pastagem no estado de Mato Grosso do Sul. Anais da Sociedade Entomológica do Brasil, 28, 527-529. http://dx.doi.org/10.1590/S0301-80591999000300020

[38] Mathys, G. and Baker, E.A. (1980) An Appraisal of Effectiveness of Quarantines. Annual Review of Phytopathology, 18, 85-101. http://dx.doi.org/10.1146/annurev.py.18.090180.000505

[39] Slater, J.A. (1964) A Catalog of the Lygaeidae of the World. 2 vols. University of Connecticut, Storrs, 437-461.

[40] Gasparich, G.E., Silva, J.G., Han, H.Y., McPheron, B.A., Steck, G.J. and Sheppard, W.S. (1997) Population Genetic Structure of Mediterranean Fruit Fly (Diptera: Tephritidae) and Implications for Worldwide Colonization Patterns. Annals of the Entomological Society of America, 90, 790-797.

[41] Vichiato, M.R.M., Silva, P.W., Couto, C.L., Pereira, L.S., Lima, M.L.P. and Prado, E. (2013) Defoliation and dieback of twigs on Ficus macrocarpa L. Trees in Belo Horizonte, Minas Gerais, Brazil. Revsbau, 8, 18-28.

[42] Tay, W.T., Soria, M.F., Walsh, T., Thomazoni, D., Silvie, P., Behere, G.T., Anderson, C. and Downes, S. (2013) A Brave New World for an Old World Pest: Helicoverpa armigera (Lepidoptera: Noctuidae) in Brazil. PLoS ONE, 8, Article ID: e80134. http://www.plosone.org/article/info\%3Adoi\%2F10.1371\%2Fjournal.pone.0080134 http://dx.doi.org/10.1371/journal.pone.0080134

[43] Lammers, J.W. and MacLeod, A. (2007) Report of Pest Risk Analysis-Helicoverpa armigera. CSL (UK). http://www.fera.defra.gov.uk/plants/plantHealth/pestsDiseases/documents/helicoverpa.pdf

[44] Marelli, C. (1930) El gorgojo de los eucaliptos halados en la Argentina no es la especie originaria de la Tasmania “Gonipterus scutelattus”. Revista de lo Museo de La Plata, 30, 257-269.

[45] Barbiellini, A.A. (1955) Combate a praga do eucalipto no Sul. Chacaras e quintais, 91, 191-192. 
[46] Iede, E.T. and Zanetti, R.A. (2007) Occurrence and Management Recommendations of Sirex noctilio Fabricius (Hymenoptera, Siricidae) on Pinus patula Plantations in the State of Minas Gerais. Revista Brasileira de Entomologia, 51, 529-553. http://dx.doi.org/10.1590/S0085-56262007000400023

[47] Truol, G., French, R., Sagadin, M. and Arneodo, J. (2004) First Report of Wheat Streak Mosaic Virus Infecting Wheat in Argentina. Australasian Plant Pathology, 33, 137-138. http://dx.doi.org/10.1071/AP03092

[48] Navia, D., Truol, G., Mendonça, R.S. and Sagadín, M. (2006) Aceria tosichella Keifer (Acari: Eriophyidae) from Wheat Streak Mosaic Virus-Infected Plants in Argentina. International Journal of Acarology, 32, 189-193. http://dx.doi.org/10.1080/01647950608684460

[49] Stenger, D.C. and French, R. (2009) Wheat Streak Mosaic Virus Genotypes Introduced to Argentina Are Closely Related to Isolates from the American Pacific Northwest and Australia. Archives of Virology, 154, 331-336. http://dx.doi.org/10.1007/s00705-008-0297-1

[50] da Silva Pereira, P.R.V., Navia, D., Salvadori, J.R. and Lau, D. (2009) Occurrence of Aceria tosichella in Brazil. Pesquisa Agropecuária Brasileira, 44, 539-542. http://dx.doi.org/10.1590/S0100-204X2009000500015

[51] Mar, T.B. (2012) Ocorrência e caracterização do Wheat Streak Mosaic Virus no Brasil. MSc Thesis Universidade de Passo Fundo, Passo Fundo, 113 p.

[52] Barbosa, J.C., Teixeira, A.P.M., Moreira, A.G., Camargo, L.E.A., Filho, A.B., Kitajima, E.W. and Rezende, J.A.M. (2008) First Report of Tomato chlorosis virus Infecting Tomato Crops in Brazil. Plant Disease, 92, 1709. http://dx.doi.org/10.1094/PDIS-92-12-1709C

[53] Albuquerque, L.C., Villanueva, F., Resende, R.O., Navas-Castillo, J., Barbosa, J.C. and Inoue-Nagata, A.K. (2013) Molecular Characterization Reveals Brazilian Tomato chlorosis virus to Be Closely Related to a Greek Isolate. Tropical Plant Pathology, 38, 332-336. http://dx.doi.org/10.1590/S1982-56762013005000016

[54] Rivas, E.B., Bodi, E.C.A. and Lobo, R.S.V. (2011) Lily Mottle Virus no Brasil. Documento Técnico 010-APTA/Instituto Biológico, 9 p.

[55] Rivas, E.B. (2010) Lily Symptomless Virus no Brasil. Documento Técnico 006-APTA/Instituto Biológico, 5 p.

[56] Mituti, T., Marubayashi, J.M., Moura, M.F., Krause-Sakate, R. and Pavan, M.A. (2011) First Report of Shallot latent virus in Garlic in Brazil. Plant Disease, 95, 227. http://dx.doi.org/10.1094/PDIS-08-10-0599

[57] Colariccio, A., Chaves, A.L.R., Chagas, C.M., Lenzi, R. and Roggero, P. (2003) Presence of Lettuce Big-Vein Disease and Associated Viruses in a Subtropical Area of Brazil. Plant Pathology, 52, 792. http://dx.doi.org/10.1111/j.1365-3059.2003.00901.x

[58] Lin, M.T. (1979) Occurrence and Host Range of Olpidium brassicae in Central Brazil. Plant Disease Reporter, 63, 1012.

[59] Sala, F.C. (2006) Reação de alface (Lactuca sativa L.) a Thielaviopsis basicola (Berk. \& Broome) Ferraris. PhD Thesis Universidade de São Paulo, 96 p.

[60] Morales, F.J., Ward, E., Castano, M., Arroyave, J.A., Lozano, I. and Adams, M.J. (1999) Emergence and Partial Characterization of Rice Stripe Necrosis Virus and Its Fungus Vector in South America. European Journal of Plant Pathology, 105, 643-650. http://dx.doi.org/10.1023/A:1008786832634

[61] Maciel, J.L.N., de Moraes, M.G., Almança, M.A.K., Matsumura, A.T.S. and Falcade, J.H. (2006) Ocorrência do vírus Rice stripe necrosis virus em lavouras de arroz do Rio Grande do Sul. Fitopatologia Brasileira, 31, 209. http://dx.doi.org/10.1590/S0100-41582006000200018

[62] McCouch, S., Baute, G.J., Bradeen, J., et al. (2013) Agriculture: Feeding the Future. Nature, 499, 23-24. http://dx.doi.org/10.1038/499023a 